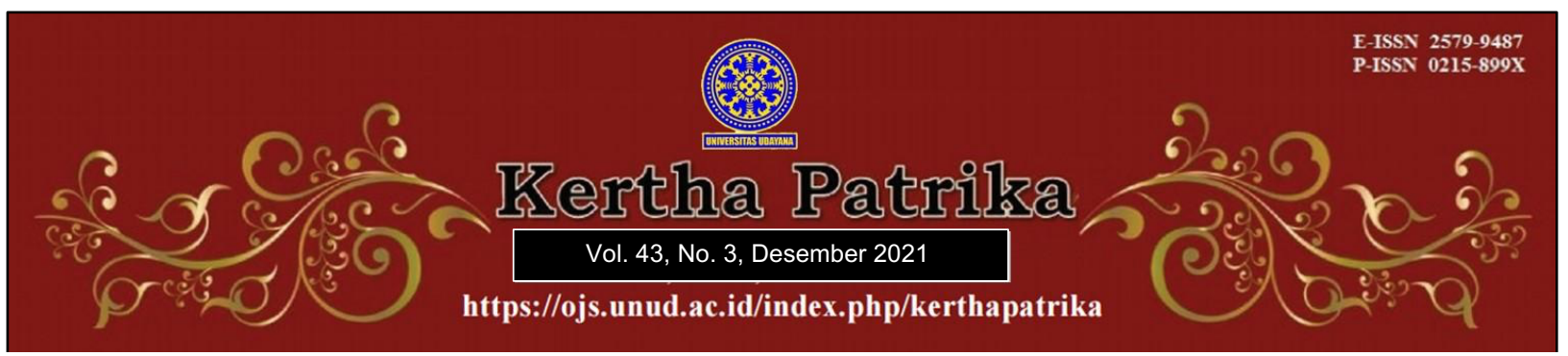

\title{
Product Reviews by YouTubers: Education or Defamation?
}

\author{
Dewi Bunga ${ }^{1}$ \\ 1Faculty of Dharma Duta Universitas Hindu Negeri I Gusti Bagus Sugriwa, \\ E-mail: bunga8287@gmail.com
}

\begin{tabular}{l}
\hline Info Artikel \\
\hline Submitted : $27^{\text {th }}$ February 2021 \\
Accepted : $12^{\text {th }}$ December 2021 \\
Published : $28^{\text {th }}$ December 2021 \\
Keywords : \\
Product Reviews, YouTuber, \\
Education, Insult, Defamation \\
\\
Corresponding Author: \\
bunga8287@gmail.com \\
DOI: \\
10.24843/KP.2021.v43.i03.p01
\end{tabular}

\begin{abstract}
One of the efforts used by YouTubers to reach subscribers is by conducting product reviews. Based on their competencies, YouTubers convey an assessment of goods and services to the public and as a form of education to the public. This practice may raise legal problems if according to the producer or related parties that the results of the assessment done actually drop the goods or services being marketed. This studydiscusses two legal issues.First; criminal policy of insult and/or defamation offenses in cyberspace, second; the principle of truth and public interest as the boundary between education or insulting and/or defamation. This study applies a normative juridical method examining the obscurity of norms regarding insult and/or defamation of product reviews submitted by YouTubers. It suggests that the criminal policy for insult and/or defamation is regulated in Article 27 paragraph (3) of Law Number 11 of 2008 concerning Electronic Information and Transactions which must be linked to Articles 310 and 311 of the Criminal Code. Youtuber's statement in assessing a product being discussed has to be free from subjective judgments. Testing the principles of truth and public interest is very important to free YouTubers from criminal charges of insult /and or defamation.
\end{abstract}

\section{Introduction}

The acceleration of information technology has provided a new space for internet users to earn income. One field of work that is currently emerging is the YouTuber profession. The existence of YouTubers is an online phenomenon. YouTuber is a term that refers to video bloggers (vloggers). YouTubers post videos regularly on the YouTube channel they manage. ${ }^{1}$ They produce a variety of content that can be accessed by internet users. According to Pérez-Torres, Pastor-Ruiz, \& Abarrou-Ben-Boubaker, YouTubers are considered by young people as peers, even though they also have qualities (creativity or talent) that they admire. They are also close to their followers in the sense that they share

1 Jerslev, A. (2016). Media times| in the time of the microcelebrity: celebrification and the YouTuber Zoella. International Journal of Communication, 10, 19: 5231. 
features (age, language, culture, social context, etc.) with the youth who follow them. This activity is even used as a profession promising abundant income. ${ }^{2}$

YouTubers have their own accounts that contain specific content according to their expertise or enjoyment. To create interesting content is certainly not easy, they must look at the market tastes. Some of the contents that are interesting and have won many subscribers include health, travel, spiritual content, podcasts and even product reviews. The contents in cyberspace are expected to provide education for YouTube users. However, some YouTubers have faced legal problems started with the educational reviews they broadcast. Some of the cases occurred include the following:

a. Starting in 2020, doctor Richard Lee did a review of Helwa cream. The review was uploaded on the Youtube channel he manages. In the video, doctor Richard Lee said that based on the results of laboratory tests, there were mercury and hydroquinone in the product. Kartika Putri, the brand ambassador for the product in question, responded by uploading a video on the Youtube channel by saying that she knew the owner of Helwa cream very well, so she dared to become a brand ambassador for the product. ${ }^{3}$ The debate between doctor Richard Lee and Kartika Putri was followed by the reporting of defamation by Kartika Putri related to the results of the product review. The topic about Doctor Richard is trending on Twitter social media, there is even an attempt to raise a petition "Save Doctor Richard" on the social media platform. ${ }^{4}$

b. Garuda Indonesia reported YouTubers Rius Vernandes and Elwiyana Monica for alleged defamation. The objects reported are Insta Story broadcasts through his Instagram account, @rius.vernandes and his YouTube account. They uploaded handwritten food menus to other passengers sitting in front of them in Garuda Indonesia's business class. The recording was done because of his disappointment not getting white wine because it ran out. For the upload, Garuda Indonesia reported the two of them on suspicion of defamation as regulated in Article 27 paragraph (3) in conjunction with Article 45 paragraph (3) and/or Article 28 paragraph (1) in conjunction with Article 45A paragraph (1) of Law Number 11 of 2008 concerning Information and Electronic Transactions (Electronic Information and Transaction Law), in conjunction with Article 310 and/or Article 311 of the Criminal Code at the Soekarno-Hatta Airport Police Station. ${ }^{5}$

2 Pérez-Torres, V., Pastor-Ruiz, Y., \& Abarrou-Ben-Boubaker, S. (2018). YouTuber videos and the construction of adolescent identity. Comunicar. Media education research journal, 26(1). 6170. doi: https://doi.org/10.3916/C55-2018-06.

3 Nadine Saksita Christi. Pada Denny Sumargo, Dokter Richard Lee Ungkap Duduk Perkara Perseteruannya Kengan Kartika Putri. Available from https://www.tribunnews.com/seleb/2021/02/09/pada-denny-sumargo-dokter-richard-lee-ungkapduduk-perkara-perseteruannya-dengan-kartika-putri. (Accesed 27 Februari 2021).

4 Nur Rohmi Aida. Dokter Richard Lee, Kartika Putri, dan Sejumlah Hal yang Perlu Diketahui Seputar Skincare. Available from https://www.kompas.com/tren/read/2021/02/06/150500265/dokter-richardlee-kartika-putri-dan-sejumlah-hal-yang-perlu-diketahui?page=all. (Accesed 27 Februari 2021).

5 Ambaranie Nadia Kemala Movanita. Bisakah YouTuber Rius Vernandes Dikenakan Pidana karena Review Pesawat? Available from https://megapolitan.kompas.com/read/2019/07/17/09191641/bisakah-youtuber-rius-vernandesdikenakan-pidana-karena-review-pesawat?page=all. (Accesed 27 Februari 2021). 
c. In early 2021, PT Eigerindo Multi Produk Industri uploaded a 'Letter of Objection' addressed to a YouTuber, Dian Widiyanarko or @duniadian. PT Eigerindo Multi Produk Industri as a producer of outdoor activities equipment objected because Dian Widiyanarko did a review of the Eiger product using the imperfect lighting. The debate occurred because he made the review by buying Eiger products himself, not based on an endorsement agreement with PT Eigerindo Multi Produk Industri. ${ }^{6}$

According to the provisions of Article 2 Information and Electronic Transactions, the use of information technology aims to educate the nation's life and must be carried out responsibly. The YouTubers upload regarding product reviews, on the one hand, are a form of education for internet users, but on the other hand, these conditions tend to cause lawsuits for them. They can be threatened with defamation and/or defamation as regulated in Article 27 paragraph (3) of Law Number 11 of 2008 concerning Information and Electronic Transactions which are flexible enough to convict someone. Criminal threats for the YouTubers conducting product reviews will certainly reduce their mission to provide education to the public or even can actually pin the public from dangerous products. In this study, the development and limitation of insults and/or defamation offenses in cyberspace will be discussed.

Research on social media content and defamation has been written by several researchers. Amalina Mashfufah in her research entitled "Kajian Hukum Jasa Endorse Dalam Media Sosial (Instagram): Studi Pada Akun Lambe Turah/_Legal Study of Endorse Services in Social Media (Instagram): Studies on Lambe Turah Accounts" discusses endorsement services through lambe turah accounts on social media (Instagram) from the perspective of DSN MUI Fatwa Number 24 of 2017 concerning Law and Guidelines Bermuamalah and Law Number 19 of 2016 concerning Information and Electronic Transactions, there are the same rules regarding defamation in social media. ${ }^{7}$ Hardianto Djanggih and Nasrun Hipan examined the "Pertimbangan Hakim dalam Perkara pencemaran Nama Baik Melalui Media Sosial (Kajian Putusan Nomor: 324/Pid./2014/PN.SGM)/ Judges' Considerations in Defamation Cases through Social Media (Study of Decision Number: 324/Pid./2014/PN.SGM)". The results of the study indicate that the judge's consideration Number 324/Pid.2014/PN.SGM Sungguminasa District Court has reflected a decision that has reflected a sense of justice. Where the judge's decision is able to explore juridical and non-juridical considerations, so that the judge in his decision finds elements of the defendant's fault in Article 27 paragraph (1) of the Electronic Information and Transaction Law, which is suspected by the public prosecutor. The judge's decision on this case is that the judge is able to explore the values that live in society, in this case the Bugis-Makassar Customs as Adat which becomes the philosophy of life in the place where the crime occurred. ${ }^{8}$ I Wayan Budha Yasa and Gede Yudiarta Wiguna researched "Konten Prank Youtuber Sebagai Tindak Pidana Berdasarkan

6 Theresia Ruth Simanjuntak. Viral Keberatan Eiger ke YouTuber, APPRI: Brand Milik Publik, Karyawan Wajib Paham Nilai Perusahaan. Available from https://megapolitan.kompas.com/read/2021/01/29/19481791/viral-keberatan-eiger-ke-youtuber-appribrand-milik-publik-karyawan-wajib?page=all. (Accesed 27 Februari 2021).

7 Mashfufah, Amalina. (2019). Kajian Hukum Jasa Endorse Dalam Media Sosial (Instagram): Studi Pada Akun Lambe Turah. Journal of Islamic Business Law, 3(1), 40-50.

8 Djanggih, Hardianto, and Nasrun Hipan. (2018). Pertimbangan Hakim dalam Perkarapencemaran Nama Baik Melalui Media Sosial (Kajian Putusan Nomor: 324/Pid./2014/PN. SGM). Jurnal Penelitian Hukum De Jure, 18(1). 93-102. doi: http://dx.doi.org/10.30641/dejure.2018.V18.93-102 
Undang-Undang Informasi dan_Transaksi Elektronik/YouTube Prank Content as a Crime Under the Electronic Information and Transaction Law." Based on the results and discussion of this research, it was found that YouTuber prank content which can be categorized as a criminal offense under the Information and Electronic Transactions Law is prank content that contains content that violates decency, insults and/or defamation, and can cause hatred or hostility of certain individuals and/or community groups based on ethnicity, religion, race, and inter-group (SARA). Then it was found that the regulation regarding YouTuber prank content which is categorized as a crime in the Electronic Information and Transaction Law is regulated in Article 27 paragraph (1) and (3) junto Article 45 paragraph (1) and (3) and Article 28 paragraph (2) junto Article 45A paragraph (2). 9

\section{Research methods}

This research was a normative juridical type examining the limitations of the provisions of Article 27 paragraph (3) of Law Number 11 of 2008 concerning Information and Electronic Transactions in product reviews. Research materials consist of primary and secondary legal materials. Primary legal materials consist of the Criminal Code, Law Number 8 of 1999 concerning Consumer Protection, Law Number 11 of 2008 concerning Information and Electronic Transactions, and Law Number 19 of 2016 concerning Amendments to Law Number 11 of 2008 concerning Information and Electronic Transactions. Secondary legal materials consist of journals and electronic articles that are relevant to this research. The research materials were collected through literature study. The interpretation of law is carried out systematically and authentically. The analysis is carried out qualitatively and presented in an analytical descriptive manner.

\section{Results and Discussion}

\subsection{Criminal Policy Offense of Insult and/or Defamation}

The marketing of a product of goods and services is currently starting to shift into digital platforms. Companies use the services of YouTubers to market the products because they are known to be able to influence consumers to try the products being marketed. Chen, J. L., \& Dermawan ${ }^{10}$ state that through marketing and influence, the company has collaborated with YouTubers to increase their sales. The majority of interviewees think that the key to influencing viewers is trust. If viewers trust the YouTuber, they can contribute positively to all aspects of their buying behavior. Although YouTubers can promote goods and services in accordance with endorsement agreements, there are also YouTubers who buy their own products that will be discussed. The purchased products will be discussed about their functions, advantages and disadvantages. This discussion is carried out independently without being asked by interested parties; therefore, the results of the discussion are an honest review.

9 Yasa, I. W. B., \& Wiguna, G. Y. (2021t). Konten Prank Youtuber Sebagai Tindak Pidana Berdasarkan Undang-Undang Informasi dan Transaksi Elektronik. In Seminar Nasional Hukum Universitas Negeri Semarang, 7(2): 631-644). doi: https://doi.org/10.15294/snhunnes.v7i2.738

10 Chen, J. L., \& Dermawan, A. (2020). The Influence of YouTube Beauty Vloggers on Indonesian Consumers' Purchase Intention of Local Cosmetic Products. International Journal of Business and Management, 15(5), 100-116. doi: https:// doi.org/10.5539/ijbm.v15n5p100. 
Theoretically, business ethics is indispensable in trading activities, both by traders who sell products and Youtubers who review product quality. To be an ethical subject is to be responsible for the others in every moment of life. ${ }^{11}$ Reviews of products purchased by YouTubers themselves are the first step to show the independence of YouTubers in providing an assessment of a product, which is very important to educate the public before using a product. Basically, the public has the right to have their opinions heard and to obtain intelligent information. Article 4 letter d of Law Number 8 of 1999 concerning Consumer Protection states that consumers have the right to submit opinions and complaints to business actors regarding the use of goods and/or services from these business actors. Article 4a of Law Number 11 of 2008 concerning Information and Electronic Transactions states that the purpose of the use of information technology and electronic transactions is to educate the life of the nation in which the information technology user community in Indonesia is part of the world information society. In accordance with these consumer rights, YouTubers have the right to submit complaints and even objective comments on a certain object or situation, as long as it does not contain an element of insult.

In the Indonesian legal system, insult and/or defamation is a crime because it has been regulated in the Criminal Code. Defamation offense refers to an attack on the good name and/or honor of another person. Judgment of the good name and/or honor of another person is certainly difficult to ascertain because it is very subjective. The criminalization of insult crimes aims to provide protection for human rights, namely to protect the good name and honor of everyone. The protection of the interests of this individual must pay attention to the general view of the community to measure whether the act committed is seen as an attack on the honor and/or good name of a person or not.12 Good name and honor are very important things for everyone, because they are related to a person's reputation in his social position in society. Everyone will try to maintain a good personal image because a good image is the initial capital in doing work.

The crime of insult is a crime that has existed for a long time. The act has been regulated in general criminal law as stated in Article 310 of the Criminal Code. The act is then transformed into a virtual world in which insults are carried out through social media. This crime is indeed a trend today. Based on PatroliSiber.od statistical data, the number of complaints of criminal acts of insult/defamation is in the second place after complaints of alleged fraud.

Figure 1 Number of public complaints through PatroliSiber.id

11 Tajalli, P., \& Segal, S. (2019). Levinas, weber, and a hybrid framework for business ethics. Philosophy of Management, 18(1), 71-88.

12 Subekti, A. S., Pradana, N. A. S., Ardhira, A. Y., \& Zulfikar, M. T. I. (2021). Tindak Pidana Pencemaran Nama Baik Melalui Facebook Menurut KUHP dan Undang-Undang Nomor 11 Tahun 2008 Tentang ITE. Jurnal Hukum \& Pembangunan, 50(3), 738-757. doi: http://dx.doi.org/10.21143/jhp.vol50.no3.2756. 


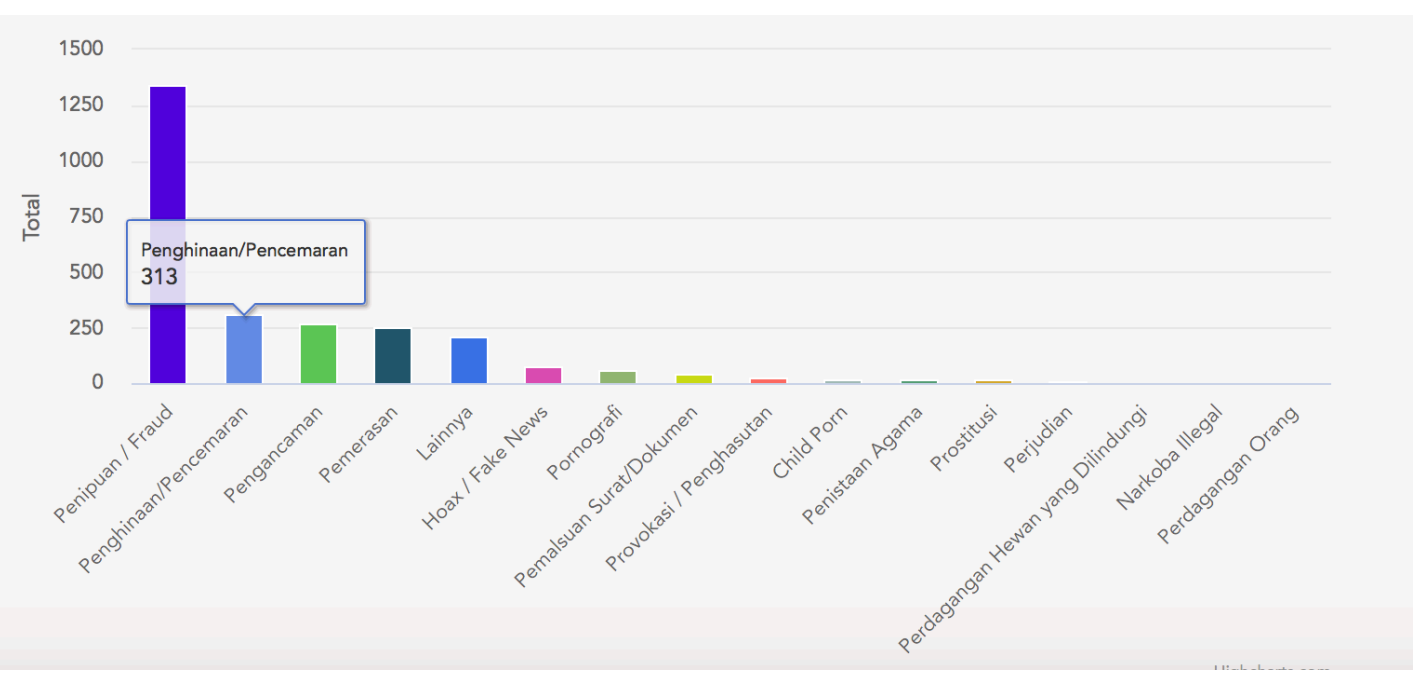

Source: https:// patrolisiber.id/home

The high incidence of insults in Indonesia, also occurs in other countries such as China. Regarding this, Yang \& Wang state that defamation among organizations is becoming more and more common in reality. In the "China Judgment Document Network" established by the Supreme Court of China, there are more than 20,000 cases of insult and defamation recorded since the establishment of the network in 2013. However, this phenomenon has been largely ignored by researchers. There are two main reasons. First, defamation is difficult to measure. Second, slander is difficult to define clearly. In recent years, research in this area has become possible due to strict legal norms, the application of big data, artificial intelligence and other methods in management research, and the disclosure of network information. Although the law punishes defamation of companies for "loss of influence and apologies", how a defamed company respond to rhetoric or symbolic actions, emphasizing positive attitudes and social values, which are essential to maintaining a company's image and reputation. ${ }^{13}$ Good name and honor is indeed a difficult thing to determine. The measure to assess the presence of defamation is certainly not the same for everyone. This is determined by the sensitivity of one's feelings, family values and the culture that follows.

The offense that may ensnare YouTubers is insult and/or defamation in cyberspace. The criminal policy is stated in Article 27 paragraph (3) of Law Number 11 of 2008 concerning Information and Electronic Transactions in which the elements of the act are every person, carried out intentionally and without rights. The act committed is the act of distributing and/or transmitting and/or making accessible Electronic Information and/or Electronic Documents, in which the Electronic Information and/or Electronic Documents in question contain insults and/or defamation." Lawmakers make acts of insult and defamation as formulated in Article 27 paragraph (3) of Law Number 11 of 2008 as equal acts. In fact, when referring to Chapter XVI of the Criminal Code, the title of the offense group is "Insults." Thus, defamation is part of insult. ${ }^{14}$

13 Yang, J., \& Wang, Y. (2019). An study of the type of interorganizational defamation risk based on Grounded Theory--an analysis from the Chinese scenario. International Journal of Frontiers in Sociology, 1(1). 75-88.

14 The qualifications for insulting offenses in the Criminal Code are as follows: 
Lawmakers seem to want to interpret insults committed in cyberspace as defamation. Judging from the regulation of offenses against insults in the Criminal Code, offenses against insults consist of general insults and special insults that are qualified according to their object. The object of common humiliation is one's self-respect and dignity. Defamation is included in the qualification of general insult. The object of special humiliation is self-respect and communal dignity. ${ }^{15}$ The provisions regarding insults and/or defamation in cyberspace (cyber defamation and cyberdenigration) as regulated in Article 27 paragraph (3) of Law Number 11 of 2008 concerning Information and Electronic Transactions only emphasize the offense of defamation as regulated in the Criminal Code. Thus, the provisions in Article 27 paragraph (3) do not contain new criminal law norms, except for additional elements that are carried out in cyberspace on information and/or electronic documents. The interpretation of Article 27 paragraph (3) of Law Number 11 of 2008 concerning Electronic Information and Transactions cannot be separated from the genus delict from these provisions, namely Article 310 and Article 311 of the Criminal Code and requires a complaint (klacht) to be processed through criminal justice.

Article 310 of the Criminal Code contains subjective and objective elements. ${ }^{16}$ The legal subject that can be punished in this provision is anyone. The objective element is the act of attacking someone's honor or reputation. The act is carried out by accusing a certain thing, with the intention that the stated thing is known to the public. The act is threatened with defamation with a maximum imprisonment of nine months or a fine. The weighting of the act of pollution is if the act is carried out in writing or with an image that is broadcast, shown or posted in public. The criminal threat for written defamation is a maximum imprisonment of one year and four months or a maximum fine of four thousand five hundred rupiahs. The legislators provide space to free anyone who declares something as an act that cannot be punished with a written defamation offense

1) General insult
a. Pollution
b. Slander
c. Mild insult
d. Slander complaint
e. False guess
f. Insult to the dead

2) Special insult
a. Insult to the President or Vice President of the Republic of Indonesia
b. Insulting the Heads of Friendly State and representatives of foreign countries in Indonesia
c. Insulting the Head of Friendly State and representatives of foreign countries in Indonesia by broadcasting, showing or pasting writings or paintings.
d. Contempt for the National Flag and Coat of Arms of the Republic of Indonesia
e. Insult to the Government of Indonesia
f. Insult to certain population groups
g. Humiliation in matters related to religion
h. Contempt for rulers and public bodies.
15 Chazawi, A. (2013). Hukum Pidana Positif Penghinaan (Edisi Revisi). Malang: Media Nusa Creative, p. 81.
16 Saroinsong, R. L. (2017). Pertanggung Jawaban Terhadap Pelaku Tindak Pidana Pencemaran Nama Baik Berdasarkan Pasal 310 KUHP. Lex Privatum, 5(7): 159-166. 
or defamation, that is, if it is done because he is forced to defend himself or in the public interest.

Article 311 of the Criminal Code formulates an act of slander, which is a maximum imprisonment of four years if the person committing the crime of defamation or written defamation is given the opportunity to prove the truth of what he is accused of, but he does not prove it. The allegations also contradict what is known. An additional penalty that can be imposed in a criminal act as formulated by Article 311 of the Criminal Code is the revocation of rights based on Article 35 No. 1 - 3 namely the right to hold positions in general or certain positions; the right to enter the Armed Forces; and the right to vote and be elected in elections held based on general rules.

The categories of defamation (written) and minor insults often show parallels as does the division between "defamation - insult" or "diffimation" and "injure". There are three things that distinguish ordinary defamation (defamation-diffimation) from minor insults, which have different legal consequences. These three things are:

a. Charge with and act or fact, namely regarding the accusation from the perpetrator. Such an accusation is a requirement for ordinary insults that is not found in "mild insults".

b. Plea of justification, which is something that can be submitted for ordinary insults if the related insults are not required for minor insults.

c. Proof of Truth, namely regarding the term proving the truth of the allegations which can be linked to Article 311 of the Criminal Code allowing for evidence if the judge deems it necessary to examine whether the defendant's actions were carried out in the public interest or because they were forced to defend themselves. The element of public interest or being forced to defend oneself has the same meaning as Article 310 paragraph (3) of the Criminal Code so that it can be used as a basis to justify an act of humiliation. Therefore, when the perpetrator of the insult realizes that he is committing an insult in the public interest (or because he is forced to defend himself), the judge allows him to prove the truth of his accusation (proof of truth). ${ }^{17}$

Criminal threats for perpetrators of insults and/or defamation in cyberspace are regulated in Article 45 paragraph (3) of Law Number 19 of 2016 concerning Amendments to Law Number 11 of 2008 concerning Information and Electronic Transactions, namely imprisonment for a maximum of 4 years and/or a maximum fine of Rp. 750,000,000.00. This provision allows the suspect not to be detained during the investigation until the judge's decision because the criminal threat does not exceed 5 years in prison. ${ }^{18}$

17 Guntara, B. (2018). Legitimasi Penyebaran Informasi Yang Memiliki Muatan Penghinaan Dan/Atau Pencemaran Nama Baik Dalam Pasal 310 KUHP Dan Undang-Undang Nomor 19 Tahun 2016 Tentang Perubahan Atas Undang-Undang Nomor 11 Tahun 2008 Tentang Informasi Dan Transaksi Elektronik. Jurnal Surya Kencana Dua: Dinamika Masalah Hukum dan Keadilan, 4(2). 250-251. doi: http://dx.doi.org/10.32493/SKD.v4i2.y2017.1071.

18 Terms of detention can be seen in Article 21 of the Criminal Procedure Code

(1) An order for further detention or detention shall be issued against a suspect or defendant who is strongly suspected of committing a criminal act based on sufficient evidence, in the event that there are circumstances raising concerns that the suspect or defendant will escape or destroy evidence and or repeat the crime. 
The criminal policy of regulating insult and/or defamation is basically to protect one's reputation. Regarding this, Dent states the concept of 'reputation' is said to be at the core of the defamation law. ${ }^{19}$ A good name is defined as a sense of self-worth, worth and dignity which the measure of this condition is a good judgment and views from the general public regarding a person's situation or personality in his social life in the midst of society. ${ }^{20}$ Lawmakers since the first time enacting this provision aim to protect a person's reputation, although it's not easy to judge a reputation. Everyone has a different reputation and self-esteem.

Honor is self-respect (eergevoel) or a feeling of honor. This feeling arises from within a person so that it is an internal matter of a person. The view of good name comes from the assessment and appreciation of the surrounding community for the attitudes, actions and position of a person in society. A good name can also be external, namely when the assessment is carried out by the experts. However, there is no common opinion regarding the meaning of honor and good name. The experts only agree that the protection of honor and reputation is the protection of human rights. The word "or" in good name or honor implies that the violation of good name or attacking honor is not a cumulative condition for insulting, but as an alternative condition. Fulfillment of only one element, in addition to other elements, has fulfilled the element of a criminal offense of humiliation. ${ }^{21}$

\subsection{The Principle of Truth and Public Interest as the Boundary Between Education or Insult and/or Defamation}

The offense of insult and/or defamation is still maintained in Indonesian criminal law. The formulation of this offense aims to protect a person's dignity and ensure ethics against acts committed in cyberspace. Enforcement of ethics is very necessary in carrying

(2) Further detention or detention is carried out by an investigator or public prosecutor against a suspect or defendant by issuing a detention order or a judge's decision stating the identity of the suspect or defendant and mentioning the reasons for detention and a brief description of the crime case suspected or accused and the place where he was detained.

(3) A copy of the warrant for further detention or detention or the determination of the judge as referred to in paragraph (2) must be given to his family.

(4) Such detention may only be imposed on a suspect or defendant who commits a criminal act and/or attempts or provides assistance in the said crime in the event that:

a. the crime is punishable by imprisonment of five years or more;

b. the crime as referred to in Article 282 paragraph (3), Article 296, Article 335 paragraph (1), Article 351 paragraph (1), Article 353 paragraph (1), Article 372, Article 378, Article 379 a, Article 453 , Article 454, Article 455, Article 459, Article 480 and Article 506 of the Criminal Code, Article 25 and Article 26 of the Rechtenordonnantie (violation of the Customs and Excise Ordinance, last amended by Staatsblad of 1931 Number 471), Article 1, Article 2 and Article 4 of the Immigration Crime Act (Law Number 8 Drt. of 1955, State Gazette of 1955 Number 8), Article 36 paragraph (7), Article 41, Article 42, Article 43, Article 47 and Article 48 Law No. 9/1976 on Narcotics (Statute Book of 1976 No. 37, Supplement to Statute Book No. 3086).

19 Dent, C. (2018). The locus of defamation law since the constitution of oxford. Monash UL Rev., 44, 491.

20 Manfaati, N. F., Setiyanto, B., \& Lukitasari, D. Urgensi Perlindungan Hukum Jurnalis Terhadap Tindak Pidana Pencemaran Nama Baik Menurut Undang-Undang Informasi Dan Transaksi Elektronik. Jurnal Hukum Pidana dan penanggulangan Kejahatan, 9(3), 220-228.

21 Setiawan, I. (2019). Kajian Terhadap Pencemaran Nama Baik Melalui Facebook. Jurnal Ilmiah Galuh Justisi, 7(1), 39-48. 44. doi: http:/ / dx.doi.org/10.25157/jigj.v7i1.2146 
out activities in the cyber world. According to Hidayat, Nurhayati, \& Rahmasari, there are several reasons why ethics in activities in cyberspace, especially in the use of social media, must be maintained. These reasons include the background of the use of social media which is so heterogeneous and comes from different environments. Communication is predominantly done in the form of text in social media. Social media that has similarities to the real world. The social media is not only used by individuals, but also by the business industry. ${ }^{22}$ The product owner will give a positive response if the YouTuber gives a good review for the product being discussed. On the other hand, if a YouTuber gives a bad rating even for the product being discussed. Then this can be a legal problem, namely defamation of the owner or brand ambassador of the product.

A YouTuber can be charged with the provisions of Article 27 paragraph (3) of Law Number 11 of 2008 concerning Information and Electronic Transactions if the act contains an element of error. The element of error as contained in the formulation of the offense of humiliation and/or defamation is in the form of an intentional element. Intentional according to legal doctrine refers to an act, in which the perpetrator knows about the act he has committed. The perpetrator is also aware that his speech contains an attack on the honor or reputation of another person or other meanings that are in line with the phrase. In this offense, there is no need for the so-called 'animus injuriandi'. Animus injuriandi is the "intentional intent to insult." The affirmation of this can be seen in the Supreme Court's decision Number 37 K/Kr/1957 dated December 21, 1957. The decision consistently states that there is no need for animus juriandi or intentional insults in fulfilling the elements of the offense. This requirement becomes important to measure a criticism or act of insulting or defaming someone. The 'animus injuriandi can be determined from the insulting sentence and the motive behind the act. ${ }^{23}$

There is no need for an animus juriandi in the tendency to make it easier for someone to be qualified as a perpetrator in a criminal act of humiliation and/or defamation. This is a weakness in the provisions for insulting and/or defamation as stated by Widhianta which it is unfortunate that the element of intent in the defamation law in the rule of law in Indonesia does not explicitly distinguish between the facts and opinions. In addition, this provision does not consider the truth in revealing a fact. Attacks on reputation or honor are considered fulfilled when the statement is considered insulting by the victim. This concept can be seen from the opinion of the Supreme Court through Jurisprudence Number $37 \mathrm{~K} / \mathrm{Kr} / 1957$ dated December 21, 1957. The decision states that there is no need to prove the animus injuriandi or the intention to insult. It of course is contrary to the theories of intentionality. It becomes a problem if the Jurisprudence of the Supreme Court Number $37 \mathrm{k} / \mathrm{kr} / 1957$ is used as the basis in cases of defamation due to coercion or in the control of others (e.g. threatened). The opinion of the Supreme Court through the decision Number $37 \mathrm{k} / \mathrm{kr} / 1957$ dated December 21, 1957 will certainly cause the justification (Article 49 of the Criminal Code) and the excuse of forgiveness (Article 48

22 Hidayat, M. F., Nurhayati, I. K., \& Rahmasari, G. (2020). Kekerasan Verbal Dalam Vlog Game Pada Kanal Youtube: Sebuah Kajian Ilmu Komunikasi. Jurnal Sosioteknologi, 19(1), 30-39. doi: https://doi.org/10.5614/sostek.itbj.2020.19.1.3.

23 Alviolita, F. P., \& Arief, B. N. (2019). Kebijakan Formulasi Tentang Perumusan Tindak Pidana Pencemaran Nama Baik Dalam Pembaharuan Hukum Pidana Di Indonesia. Law Reform, 15(1), 130-148. doi: https:/ / doi.org/10.14710/1r.v15i1.23359. 
of the Criminal Code) as a condition for the abolition of a criminal act to become invalid. ${ }^{24}$

In the practice of criminal acts of humiliation, the teaching of animus injuriandi develops. According to this teaching, the perpetrator can be punished when the conditions are fulfilled in the form of awareness or knowledge of the perpetrator that the statement he conveys will result in or can attack the honor or good name of another person even though the purpose of the perpetrator is not to insult the person in question. Offenders can also be punished even though it can be proven that he did not intentionally insult. This is because the insult has arisen as a result of the verbal statement or written statement. ${ }^{25}$ Brown argues for the consequences of the animus injuriandi doctrine, where Brown argues that consequently, despite what the animus injuriandi terminology implies, there is no need for a design to actively cause insults. Iniuria can be perpetrated by a person who insults the personal interests of another through a misplaced zeal such as when someone acts intentionally to injure. ${ }^{26}$

The principle of truth to limit a YouTuber's statement is an education or even an insult and/or defamation. This principle must meet several requirements. First, a statement that is true is judged if it has been proven in a court decision that has permanent legal force. Second, the truth conveyed is carried out in the public interest. Third, the statement submitted is true based on a court decision which has an applied legal force but is used by the perpetrator to attack and harm (bully) other parties. Based on these limitations, the truth conveyed must be based on the public interest. ${ }^{27}$

Victims are given the opportunity to prove that what is conveyed is not true. In this regard, Arbel \& Mungan state the final justification for the defamation law is that victims of defamation can defend their reputation by proving false accusations. The importance of justification goes beyond legal remedies. Defamation, however, involves another's viewing and esteem of a person in the community. Through the process of adjudication, individuals can save themselves in the eyes of others and regain their former selfesteem. ${ }^{28}$ People who are interested in the review submitted by YouTubers can submit a rebuttal to the statement addressed to them as something that is not true and even though it is true, it is not submitted for the public interest.

An allegation that a YouTuber makes to qualify as insult and/or defamation does not have to be a false allegation or an untrue statement. According to Arrest Hoge Raad in 1899 , even though the allegations made contain the truth, if they are not carried out in

24 Widhianta, V. D. Relevansi Konstruksi Pasal Pencemaran Nama Baik Sebagai Sarana Strategic Lawsuit Againts Public Participation (Slapps) Dalam Konflik Lingkungan Hidup. Jurnal Hukum Pidana dan penanggulangan Kejahatan, 3(3), 345-355.

25 Prahassacitta, V., \& Hasibuan, B. M. (2019). Disparitas Perlindungan Kebebasan Berekspresi Dalam Penerapan Pasal Penghinaan Undang-Undang Informasi Dan Transaksi Elektronik. Jurnal Yudisial, 12(1), 61-79. doi: http:// dx.doi.org/10.29123/jy.v12i1.299

26 Brown, J. (2020). Detention of private persons by private persons as a delictual wrong: liability for deprivation of liberty in Scots private law. University of St. Andrews Law Journal, 1(1), 4155.

27 Rohmana, N. Y. (2017). Prinsip-Prinsip Hukum Tentang Tindak Pidana Penghinaan Dan Pencemaran Nama Baik Dalam Perpspektif Perlindungan Hak Asasi Manusia. Yuridika, 32(1), 105-133. doi: http://dx.doi.org/10.20473/ydk.v32i1.4831.

28 Arbel, Y. A., \& Mungan, M. (2019). The Case Against Expanding Defamation Law. Ala. L. Rev., 71, 453. 
the public interest, but for the personal interests of those who make statements to offend feelings, then acts of blasphemy or insulting or defaming really take place. Arrest Hoge Raad in 1934 and 1938 in considering the matter of publication in the public interest state that publication in a tone of anger and blaming someone could not be said to be a defense of the public interest. ${ }^{29}$ Article 28J of the 1945 Constitution in principle states that everyone is obliged to respect the human rights of others, but in fulfilling them, everyone is obliged to comply with the restrictions stipulated by law with the sole purpose of guaranteeing recognition and respect for the rights of freedom of others and to fulfill demands. justice in accordance with considerations of morality, religious values, security, and public order in a democratic society. YouTubers are said to provide education to the public if it is done with the principle of truth and in the public interest, without any personal interest from them for their statements in product reviews concerned. Objectivity in submitting the results of the review is very necessary to exonerate YouTubers from accusations of insults and slander or defamation.

\section{Conclusion}

The criminal policy for offenses against insults and/or defamation in cyberspace is regulated in Article 27 paragraph (3) of Law Number 11 of 2008 with the genus delicti Article 310 and 311 of the Criminal Code. Normatively, YouTubers can be freed from the bondage of insulting offenses and / defamation if the results of the review contain the truth and are intended for the public interest. Nevertheless, YouTubers' good intentions to provide education to the public are very vulnerable to being punished with insults and/or defamation offenses in cyberspace, if the results of the product review are not in line with the expectations of producers or other related parties. Legally, YouTubers are not the competent authority, even though they have the competence to provide scientific explanations for the products discussed. The element of intent in the offense of defamation and/or defamation does not require proof of animus injuriandi (deliberate intention to insult). As a result, insult and/or defamation offenses can ensnare YouTubers if the relevant parties object to the results of product reviews on YouTube contents that are broadcasted.

\section{Acknowledgments}

Thank you to Mrs. Sri Wiyanti Eddyono, S.H., LLM (HR)., Ph.D. for all the input both in the substance of the writing as well as in the technique and research methodology.

\section{Bibliography / Reference List}

\section{$\underline{\text { Books }}$}

Chazawi, A. (2013). Hukum Pidana Positif Penghinaan (Edisi Revisi). Malang: Media Nusa Creative.

Lamintang P.A.F. dan Djisman S. (1990). Hukum Pidana Indonesia. Bandung: Sinar Baru.

29 P.A.F. Lamintang dan Djisman S., Hukum Pidana Indonesia (Bandung: Sinar Baru, 1990), hal. 188-189. 


\section{Journals}

Alviolita, F. P., \& Arief, B. N. (2019). Kebijakan Formulasi Tentang Perumusan Tindak Pidana Pencemaran Nama Baik Dalam Pembaharuan Hukum Pidana Di Indonesia. Law Reform, 15(1), 130-148. doi: https://doi.org/10.14710/ lr.v15i1.23359.

Arbel, Y. A., \& Mungan, M. (2019). The Case Against Expanding Defamation Law. Ala. L. Rev., 71, 453.

Brown, J. (2020). Detention of private persons by private persons as a delictual wrong: liability for deprivation of liberty in Scots private law. University of St. Andrews Law Journal, 1(1), 41-55.

Chen, J. L., \& Dermawan, A. (2020). The Influence of YouTube Beauty Vloggers on Indonesian Consumers' Purchase Intention of Local Cosmetic Products. International Journal of Business and Management, 15(5), 100-116. doi: https://doi.org/10.5539/ijbm.v15n5p100.

Dent, C. (2018). The locus of defamation law since the constitution of oxford. Monash UL Rev., 44, 491.

Dharmawan, N. K., Sarjana, M., \& Samshitawrati, P. A. (2018). Perusahaan Dan Konservasi Keanekaragaman Hayati Laut: The Right To Tourism Vs Sustainable Tourism. Masalah-Masalah Hukum,46(2), 125-135. doi:10.14710/mmh.46.2.2017.125-135.

Djanggih, Hardianto, and Nasrun Hipan. (2018). Pertimbangan Hakim dalam Perkarapencemaran Nama Baik Melalui Media Sosial (Kajian Putusan Nomor: 324/Pid./2014/PN. SGM). Jurnal Penelitian Hukum De Jure, 18(1). 93-102. doi: http:/ /dx.doi.org/10.30641/dejure.2018.V18.93-102

Felice, D. D. (2015). Business and Human Rights Indicators to Measure the Corporate Responsibility to Respect: Challenges and Opportunities. Human Rights Quarterly,37(2), 511-555. doi:10.1353/hrq.2015.0031.

Guntara, B. (2018). Legitimasi Penyebaran Informasi Yang Memiliki Muatan Penghinaan Dan/Atau Pencemaran Nama Baik Dalam Pasal 310 Kuhp Dan UndangUndang Nomor 19 Tahun 2016 Tentang Perubahan Atas Undang-Undang Nomor 11 Tahun 2008 Tentang Informasi Dan Transaksi Elektronik. Jurnal Surya Kencana Dua: Dinamika Masalah Hukum dan Keadilan,4(2). doi: http://dx.doi.org/10.32493/SKD.v4i2.y2017.1071.

Hidayat, M. F., Nurhayati, I. K., \& Rahmasari, G. (2020). Kekerasan Verbal Dalam Vlog Game Pada Kanal Youtube: Sebuah Kajian Ilmu Komunikasi. Jurnal Sosioteknologi, 19(1), 30-39. doi: https:// doi.org/10.5614/sostek.itbj.2020.19.1.3. Jayantara, M. (2015). Instrumen Rekomendasi DPRD Dalam Penyelenggaraan Kewenangan Perijinan Oleh Pemerintah Daerah. Jurnal Magister Hukum Udayana (Udayana Master Law Journal),4(3). doi:10.24843/jmhu.2015.v04.i03.p07

Jerslev, A. (2016). Media times | in the time of the microcelebrity: celebrification and the YouTuber Zoella. International Journal of Communication, 10, 19: 5231.

Manfaati, N. F., Setiyanto, B., \& Lukitasari, D. Urgensi Perlindungan Hukum Jurnalis Terhadap Tindak Pidana Pencemaran Nama Baik Menurut Undang-Undang 
Informasi Dan Transaksi Elektronik. Jurnal Hukum Pidana dan penanggulangan Kejahatan, 9(3), 220-228.

Mashfufah, Amalina. (2019). Kajian Hukum Jasa Endorse Dalam Media Sosial (Instagram): Studi Pada Akun Lambe Turah. Journal of Islamic Business Law, 3(1), 40-50.

Pérez-Torres, V., Pastor-Ruiz, Y., \& Abarrou-Ben-Boubaker, S. (2018). YouTuber videos and the construction of adolescent identity. Comunicar. Media education research journal, 26(1). 61-70. doi: https:// doi.org/10.3916/C55-2018-06.

Prahassacitta, V., \& Hasibuan, B. M. (2019). Disparitas Perlindungan Kebebasan Berekspresi Dalam Penerapan Pasal Penghinaan Undang-Undang Informasi Dan Transaksi Elektronik. Jurnal Yudisial, 12(1), 61-79. doi: http://dx.doi.org/10.29123/jy.v12i1.299

Rohmana, N. Y. (2017). Prinsip-Prinsip Hukum Tentang Tindak Pidana Penghinaan Dan Pencemaran Nama Baik Dalam Perpspektif Perlindungan Hak Asasi Manusia. Yuridika, 32(1), 105-133. doi: http://dx.doi.org/10.20473/ ydk.v32i1.4831

Saroinsong, R. L. (2017). Pertanggung Jawaban Terhadap Pelaku Tindak Pidana Pencemaran Nama Baik Berdasarkan Pasal 310 KUHP. Lex Privatum, 5(7): 159166.

Setiawan, I. (2019). Kajian Terhadap Pencemaran Nama Baik Melalui Facebook. Jurnal Ilmiah Galuh Justisi,7(1), 39-48. 44. doi: http://dx.doi.org/10.25157/ jigj.v7i1.2146

Subekti, A. S., Pradana, N. A. S., Ardhira, A. Y., \& Zulfikar, M. T. I. (2021). Tindak Pidana Pencemaran Nama Baik Melalui Facebook Menurut KUHP dan UndangUndang Nomor 11 Tahun 2008 Tentang ITE. Jurnal Hukum \& Pembangunan, 50 (3), 738-757. doi: http://dx.doi.org/10.21143/jhp.vol50.no3.2756

Tajalli, P., \& Segal, S. (2019). Levinas, weber, and a hybrid framework for business ethics. Philosophy of Management, 18(1), 71-88.

Utama, I.M.A., and Suharta, I.N. (2018). The Challenges of Water Pollution: Enforcement of Water Pollution Control. Hasanuddin Law Review, 4(1): 81-87 DOI: 10.20956/halrev.v4i1.1414

Widhianta, V. D. Relevansi Konstruksi Pasal Pencemaran Nama Baik Sebagai Sarana Strategic Lawsuit Againts Public Participation (Slapps) Dalam Konflik Lingkungan Hidup. Jurnal Hukum Pidana dan penanggulangan Kejahatan, 3(3), 345-355.

Widiatedja, I. G., \& Wairocana, I. G. (2017). The Lack of the Environmental Concern in Indonesia's Bilateral Investment Treaties. Hasanuddin Law Review,3(3), 231-245. doi:10.20956/halrev.v3i3.1202

Yang, J., \& Wang, Y. (2019). An study of the type of interorganizational defamation risk based on Grounded Theory--an analysis from the Chinese scenario. International Journal of Frontiers in Sociology, 1(1). 75-88.

Yasa, I. W. B., \& Wiguna, G. Y. (2021t). Konten Prank Youtuber Sebagai Tindak Pidana Berdasarkan Undang-Undang Informasi dan Transaksi Elektronik. In Seminar 
Nasional Hukum Universitas Negeri Semarang, 7(2): 631-644). doi: https://doi.org/10.15294/snhunnes.v7i2.738

\section{Online/World Wide Web:}

Ambaranie Nadia Kemala Movanita. Bisakah YouTuber Rius Vernandes Dikenakan Pidana karena Review Pesawat? Available from https://megapolitan.kompas.com/read/2019/07/17/09191641/bisakah-youtuber-riusvernandes-dikenakan-pidana-karena-review-pesawat?page=all. (Diakses 27 Februari 2021).

Nadine Saksita Christi. Pada Denny Sumargo, Dokter Richard Lee Ungkap Duduk Perkara Perseteruannya dengan Kartika Putri. Available from https://www.tribunnews.com/seleb/2021/02/09/pada-denny-sumargo-dokter-richardlee-ungkap-duduk-perkara-perseteruannya-dengan-kartika-putri. (Diakses 27 Februari 2021).

Nur Rohmi Aida. Dokter Richard Lee, Kartika Putri, dan Sejumlah Hal yang Perlu Diketahui Seputar Skincare. Available from https://www.kompas.com/tren/read/2021/02/06/150500265/dokter-richard-leekartika-putri-dan-sejumlah-hal-yang-perlu-diketahui?page=all. (Diakses 27 Februari 2021).

Theresia Ruth Simanjuntak. Viral Keberatan Eiger ke YouTuber, APPRI: Brand Milik Publik, Karyawan Wajib Paham Nilai Perusahaan. Available from https://megapolitan.kompas.com/read/2021/01/29/19481791/viral-keberatan-eiger-keyoutuber-appri-brand-milik-publik-karyawan-wajib?page=all. (Diakses 27 Februari 2021). 